\title{
Role of fever in infection: has induced fever any therapeutic potential in HIV infection?
}

Hypothesis

\author{
R S Morton, Sakina Rashid
}

Ancient societies had no rational understanding of fever. The Greeks were the first to recognise $\frac{3}{2}$ that it may be part of nature's method of effecting cure in some diseases. How best to assist $?$ nature went through many trials and errors. Appreciation of the prognostic value of fever and $\overrightarrow{\vec{F}}$ how it may be controlled was slow to appear. That there was a place in the therapeutic arsenal for induced fever came only with the 20th century. Finding a suitable, safe, and satisfactory means came slowly. The curative power of well controlled and reproducible levels of fever was proved by $\frac{\bar{\rho}}{\square}$ the arrest of one deadly and incurable complication of a sexually transmitted disease in the first $\stackrel{\mathbb{D}}{\square}$ half of this century. The purpose of this review is to promote discussion and, hopefully, well ordered laboratory and clinical trials aimed at learning whether or not induced fevers have a $\vec{\circ}$ place in the care of patients with HIV/AIDS.

(Genitourin Med 1997;73:212-215)

Keywords: history; fever; HIV/AIDS

"Diseases, desperate grown, By desperate appliances are reliev'd Or not at all."

Shakespeare's Hamlet, Act iv; iii, 9-11.

\section{In ancient times}

While the Chinese of four to five thousand years ago declared fever to result from a loss of balance between elements controlling health, the Hindus said it was the result of unwelcome visits by fire demons. The ancient Egyptians appear to have viewed fever as an acceptable fact of life. They classified it as high or mild, and sought the help of their gods to prevent it. The Hebrews, and later the Christians, considered fever to be a divine form of punishment. Only in Mesopotamian medicine does fever seem to have been noted as commonly associated with local inflammation.

In the last 500 years BC, Hindu and Greek medicine made much of the imbalance of the humours. There were three of these-bile, phlegm, and air in the Hindu version, and four-yellow and black bile, phlegm, and blood in the Greek. The Greeks later classified fevers according to their associated diseases. They were assisted in this by Heron of Alexandria, who invented the thermoscope in the second century BC. It was Hippocrates (460 to about $377 \mathrm{BC}$ ) who first declared that fever was beneficial and that it was nature's way to cure. It "cooked", he said, "the excess humour of yellow bile". "Nature's way", he said, "should be augmented by using starvation and fluids as adjuvans". ${ }^{1}$ To this regime Galen (AD 130-200) added blood letting. It is another Greek, Rufus of Ephesus, who is credited with first recommending fever as therapy. He used it as sole treatment in epilepsy. ${ }^{2}$

\section{The Middle Ages}

In the Middle East and Near East the new faith of Mohammed (about AD 570-632) was increasing medical as well as social awareness. The works of Galen and others were available in Arabic and Syriac translations. This was to lead Rhazes ( $\mathrm{AD}$ 864-923) in his 25 volume work Contents of health to distinguish the fever of disease from that of heat stroke and that resulting from fiercely sustained physical activity. Theology and, to a lesser extent, philosophy dominated medical practice in Europe for many centuries and thus delayed advances in anatomy and physiology as well as pathology. The epidemics of the Black Death in the 14th century confirmed, for many of Europe's devout, that disease and fever were indeed divine punishments. The many ensuing deaths ended the feudal system; people realised that $\tilde{\sigma}$ with fewer of them they had a new freedom from constraints. Thus was the Renaissance heralded.

\section{The Renaissance to the 19th century}

As science as well as art began to flourish, fever was addressed anew. Galileo improved the thermoscope in 1592 and in 1644 Ferdinand I of Tuscany invented the first thermometer. Thus classification of fevers became more precise. There was the "continuous" 8 type of typhus; the "eruptive" of smallpox and measles, and the "intermittent" of malaria with its subdivisions such as tertian and quartan. With the 18 th century came the alcohol thermometer and Boerhaave's simplified classification of fever as a sign with a recognisable cause or as idiopathic - that is, with a cause still to be recognised. Associated rigors and deliriums, like fever itself, were said to be due 
to spasm of the arteries in association with disturbance of the only humour still recognised, blood.

With the 19th century, fever was well established as an essential feature of many symptom complexes. The invasion of the "idiopathic" division led to the recognition of fever as a disease in its own right-for example, jail fever and hospital fever. ${ }^{3}$ All changed dramatically when the "germ theory" became reality with the discovery of the typhoid bacillus in 1880 and the tubercle bacillus in 1882. With its status as a clinical sign ever more scientifically based, fever's benefits, excesses, prognostic value, and possible control by antipyretics were ever more widely appreciated.

Fever was seen as a useful addition to semiology or semiotics, the specialty of clinical observation as a basis for well directed laboratory research. A simple example comes from gonorrhoea. In acute pelvic inflammatory disease, gonococci were not commonly found by either Gram stained smears or cultures. Repeat tests, when local temperature rises of inflammation and general fever had subsided, not infrequently yielded positive results (Pick $\mathbf{R}$, personal communication). Thus, gonococci were labelled thermolabile and this observation led later to the recognition that in the laboratory gonococci were grown more easily at temperatures below $98 \cdot 4^{\circ} \mathrm{F}\left(37 \cdot 0^{\circ} \mathrm{C}\right)$.

\section{The present century}

At its most sophisticated, the contribution of fever to semiology reached its apogee in the observations and work of Wagner von Jauregg. As early as 1887 he observed that when infections with fever spread through his psychiatric wards the mental state of some patients improved. ${ }^{4}$ They were those suffering from syphilitic paresis (general paralysis of the insane, GPI). From first sign to death was seldom longer than three to five years, and there was no cure. Wagner von Jauregg gave such patients repeated fever using tuberculin in some and typhoid vaccine in others, with little effect. Active infection was indicated. $\mathrm{He}$ infected nine patients with tertian malaria and reported favourable results. ${ }^{5}$ In 1922 he was able to report complete remission in 46 of 200 patients treated with repeated tertian malaria fevers. All 46 were able to return to their former employment; others improved. Confirmation of his findings soon appeared from many parts of the Western world. The figure of $20 \%$ of psychiatric beds occupied by the syphilitic insane began to fall. In 1927 Wagner von Jauregg was awarded the Nobel prize for medicine.

For some physiologists the call was back to basics. As measured in the closed mouth with a mercury thermometer the body's normal temperature was $98.4^{\circ} \mathrm{F}$ in Europe and $98.6^{\circ} \mathrm{F}$ in America. Both were equated with $37^{\circ} \mathrm{C}$. The rectal temperature was $1^{\circ} \mathrm{F}$ higher and, if measured in the armpit, $1^{\circ} \mathrm{F}$ lower. Clothed skin temperature varied between $85^{\circ} \mathrm{F}$ and $94^{\circ} \mathrm{F}$. Temperature was found to vary during the day by as much as $1 \cdot 0-1 \cdot 5^{\circ} \mathrm{F}$, being lowest at 4 am and highest at $6 \mathrm{pm}$. Muscular activity generated heat. Thus a four mile walk, completed in one hour, raised the temperature $2^{\circ} \mathrm{F}$ while after a three mile race the rise might be as much as $6^{\circ} \mathrm{F}$. As regards losing heat, and reestablishing the normal balance between manufacture and loss, about $25 \%$ of heat loss was found to be accomplished via the lungs and most of the remainder by conduction, convection, radiation, and, particularly, evaporation of sweat. Adaptation to hot working conditions is generally accomplished within a few days. In the second world war, acclimatisation of UK soldiers to Middle East summer temperatures was well under way after two weeks but complete only after a total of four to six weeks. Diagnosis of heat or sun stroke generally meant a failure of adequate sweating and a subsequent temperature varying between $107^{\circ} \mathrm{F}$ and $110^{\circ} \mathrm{F}\left(44^{\circ} \mathrm{C}\right.$ and $\left.49^{\circ} \mathrm{C}\right)$. A recent report ${ }^{6}$ tells us that a $2^{\circ} \mathrm{F}$ rise in body temperature can be produced in 20 minutes in a sauna bath house operating at $80^{\circ} \mathrm{C}$. Such exposures are associated with plasma adrenocorticotrophin and cortisol activation, more in women than in men. Mid 19th century attempts to produce fever by injecting pus into animals, and later humans, caused much confusion. It was not until nearly half way through the present century before it was appreciated that it was products of Gram negative bacteria that prompted white cells to produce a precipitor of fever. It was called leucocyte pyrogen. It later became apparent that fever, natural or induced, generally caused not only leuococytosis with enhanced potential for phagocytosis but that mononuclear cells produced interleukin 1, a substance with a capacity to produce fever. Simultaneously, interleukin activated $T$ cell lymphocytes to produce interferon and interleukin 2 as well as to stimulate B cell lymphocytes to synthesise immunoglobulins.

The degrees of these cellular and biochemical responses and their associated degree of fever were shown to accelerate recovery from Escherichia coli cystitis, salmonella infection, and infections produced experimentally in animals. By contrast, the relative absence of high fever in cases of acute pneumonococcal meningitis became recognised as a declaration of poor prognosis. In addition, it was found that the exhibition of antipyretics may be associated with depressed or delayed leucocyte responses and even suppression of antibody production. The general conclusion at this stage of research was that fever was generally a helpful adaptive response not only with a capacity to accelerate recovery but with survival value.

Temperature rises of varying levels, both local and general, were explored using a variety of fever inducing agents. Stokes et $a l^{7}$ for example, quote the work of Schamberg and Rule who observed that rabbits could be protected from syphilis, after intratesticular inoculation of Treponema pallidum, if they received 11 consecutive daily hot baths producing an average temperature rise to $40^{\circ} \mathrm{F}$. Subsequent work showed that the thermal death point of $T$ 
pallidum varied both with the temperature and its duration. Other studies reported similar variations in cellular responses. There may, for example, be a period of leucopenia before leuococytosis; leucocytes were not always more numerous than lymphocytes and in some cases macrophagocytosis was a feature. Such findings prompted closer observation of patients with leukaemia and Hodgkin's disease, in whom fever is not uncommon and interleukin is sometimes abundant. When both of these features were recognised and the affected child contracted measles, this was associated with a degree of regression of the malignant condition. Fever in other malignancies was less favourable.

In the hope that predictable cellular and biochemical responses, artificially induced, might benefit other conditions, with no recognisable infectious basis, groups of patients with rheumatoid arthritis and others with asthma were given courses of "fever therapy". Improvements were modest and of limited duration.

That it was infections in humans that were most likely to benefit from fever therapy was supported by a wide variety of laboratory experiments. For example, rabbits inoculated with streptococci from a case of erysipelas were bathed regularly in warm water. The subsequent body temperature rises were found to depress bacterial growth and to be associated with clinical improvement. Clearly, bacterial and treponemal infections respond to temperature rises and appear to have a measurable and different thermal death point.

What about other groups of organisms? Reiter's disease with its associated joint disease is the only form of recurrent and chronic multiple arthritis known to be precipitated by an organism, the genitourinary Chlamydia trachomatis (serovars $\mathrm{D}-\mathrm{K}$ ). Organisms are not always demonstrable. This association of

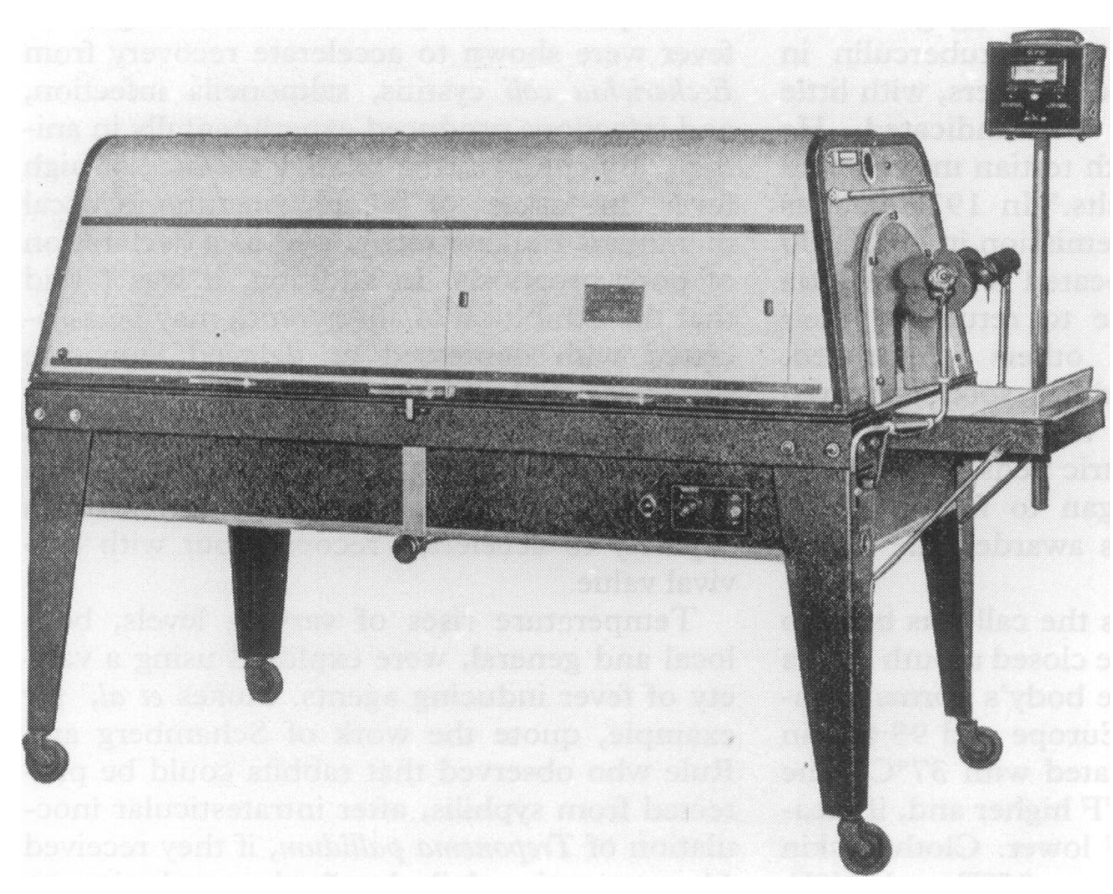

Hypertherm or "hot box" similar to this one regularly used in the 1940s by one of the authors (RSM).
Reiter's disease with an infectious agent was established in the mid and late 1960 s, some 20 years after the benefits of fever therapy (with tetracycline) were seen as the treatment of choice for the condition. ${ }^{8}$ Fever in many of these cases, during and after the 1940 s, was produced by a hypertherm ("hot box") (figure), introduced in the late 1930 s to replace malaria for the treatment of syphilitic insanity. No trace of three hypertherms known to have been used in the UK in the 1940s has been found.

Fever was induced in the hypertherm by conditioned air produced by five $200 \mathrm{~W}$ heating $\overrightarrow{\vec{F}}$ bulbs. The patient's rectal temperature was recorded and monitored outside the cabinet The patient's temperature was raised to $\frac{\bar{m}}{7}$ between $105^{\circ} \mathrm{F}$ and $106^{\circ} \mathrm{F}\left(43^{\circ} \mathrm{C}\right.$ approxi- $\stackrel{\odot}{\circ}$ mately) over some two to two and a half hours and so maintained for five hours. The temperature generally returned to normal within $30 \%$ minutes of switching off. In paresis, six fevers $\vec{\omega}$ at twice weekly intervals were routine. In cases of Reiter's disease, two fevers only were the usual. Patients were under the constant care of $\omega$ an experienced nurse. Stokes et $a l^{7}$ give full details of the use of the hypertherm.

What about viruses and induced fever? Lowff ${ }^{9}$ reviewed the available research data in 1959. Laboratory studies using chick embryos, eggs, and mice dealt with influenza, herpes, $\overparen{\Phi}$ myxoma, polio, Coxsackie, and vaccinia $\vec{\bullet}$ viruses. Replication yields dropped as temperatures rose from $37^{\circ} \mathrm{C}$ to $41^{\circ} \mathrm{C}$. The review revealed that as long ago as 1942 , thermal death points for herpes, myxoma, and vaccinia $\bar{\partial}$ viruses were defined as $40^{\circ} \mathrm{C}, 42^{\circ} \mathrm{C}$, and $45^{\circ} \mathrm{C} \stackrel{\circ}{\circ}$ respectively. ${ }^{10}$ Similar studies involving the $\odot$ HIV and hepatitis viruses have shown how $\overrightarrow{\overrightarrow{0}}$ pasteurisation of serum specimens safeguards 3 the health of laboratory workers. ${ }^{11}$ In an equally useful practical application, HIV infected human milk pasteurised at $52.5^{\circ} \mathrm{C}$ for $\stackrel{\infty ?}{=}$ 30 minutes was shown to be safe by repeatedly negative cultures and subcultures. ${ }^{12}$ Some measure of the virulence of HIV is reflected in the findings that it survives laboratory storage at $-70^{\circ} \mathrm{C}^{13}$ and that temperatures of over $60^{\circ} \mathrm{C}$ are required to kill it. ${ }^{14}$

In spite of the lack of promise in this last observation, there have been attempts to apply o "whole body" hypertherm treatment to $N$ patients with AIDS. The technology involved $\mathrm{N}^{\mathrm{N}}$ is akin to dialysis. Blood from HIV positive patients is heat treated extracorporeally at 0 $42^{\circ} \mathrm{C}$ for one hour, heated to $49^{\circ} \mathrm{C}$, cooled, and returned to the patient. In a series of 31 AIDS patients with Kaposi's sarcoma submitted to this treatment, regression of the malig- $\mathbb{\mathbb { D }}$ nancy remained in 20 for 20 days, in 14 for $\mathbb{\AA}$ 120 days, and in four for 360 days. Most patients lived longer than expected. One patient was culture and polymerase chain reac- 응 tion (PCR) negative at 26 months. Two patients died as a result of this treatment. ${ }^{15} \mathrm{~A}$ pilot study report on a second major trial, involving "whole body" (not defined) hyperthermia at $40^{\circ} \mathrm{C}$ and $42^{\circ} \mathrm{C}$ gives similar results. The clinical results are said to be dependent on HIV RNA reductions ${ }^{16}$; other workers have 
suggested reverse transcriptase activity-that is, RNA reduction is effected indirectly by suspension of transcription factors (specific proteins) which have the capacity to active production of the enzyme RNA polymerase. ${ }^{17}$

Pennypacker et $a l^{18}$ have shown that HIV suffers a $25 \%$ inactivation on exposure to a temperature of $42^{\circ} \mathrm{C}$ and that the susceptibility of infected cells to heat is increased in the presence of tumour necrosis factor as well as to a range of 10 commonly used drugs. A mathematical model, visualising whole body (not defined) hyperthermia as daily therapy, envisages a $20-40 \%$ restoration of $\mathrm{CD} 4$ cell counts.

\section{Discussion}

As a rapidly reproducing retrovirus, HIV has at least five points in its growth cycle when it is at its most vulnerable. Pakianathan ${ }^{19}$ has detailed the form and function of some of the involved molecules. Individual antiretroviral agents have been deployed against these, singly and in pairs, and no doubt are soon to be deployed in threes or even fours at the same time. Would an adjuvant's role for induced fever be worth exploring? The present state of affairs has affinities with the syphilitic insanity story. The then available trivalent arsenicals failed to breach the blood-brain barrier. Malarial fever therapy ruled alone until, in Liverpool, a pentavalent arsenical was produced (Laird SM, personal communication).

Is there something of a parallel in today's story? Levy ${ }^{20}$ points out that, to date, treatment in HIV/AIDS is directed at extracellular and circulating HIV particles. He suggests the development of drugs capable of entering infected lymphocytes. If Pennypacker et $a l^{18}$ are right, such an accomplishment might possibly render HIV sensitive to whole body hypertherm (hot box) induced fevers.

Fever might have a place worthy of exploration in other areas of illness. Is there any means whereby killer cells and CD8 lymphocytes can be made more effective? What happens to these cells when patients with HIV/AIDS have a fever? Again, can the capacity of HIV for genetically determined character change be exploited? Is there a degree of heat exposure that can stimulate such changes? Is there any way that heat exposure can produce a variant with potential for vaccine production?

\section{Conclusions}

It is clear that fever, natural or induced, has a capacity to effect or assist the curative and perhaps preventive processes. Heat, like other cidal agents, acts effectively by direct killing as well as by interfering with the molecular biochemistry of viral reproduction. Fever has the unique additional ability to enhance defence responses, both cellular and humoral. At a time when a decade and more has confirmed the limitations of available therapies, induced whole body (hot box) fever as a possible useful adjuvant to existing and developing drugs seems worthy of consideration and investigation.

1 Chadwick J, Manor WN. The medical works of Hippocrates (translation). Book 1. Epidemics. Oxford: Blackwell Scientific Publications, 1950:204-35.

2 Major RH. $A$ history of medicine. Springfield, IL: CC Thomas, 1954:174-88.

3 Wood WB. Studies on the cause of fever. $N$ Engl $f$ Med 1958;258:1023-31.

4 Wagner von Jauregg J. Ueber die Einwirking febuhafter Enkrankungen auf Psychosen. fahrbuch fur Psychiatrie Enkrankungen

5 Wagner von Jauregg J. Ueber die Einwirking der Malaria auf die progressive Paralyse. Psychiat-neural Wschr 1918-19;20:132-4, 251-5.

6 Jezova $D$, Kvetnansky $R$, Vigas $M$. Sex differences in endocrine response to hyperthermia in sauna. Acta Physiol Scand 1994;150:293-8.

7 Stokes JH, Beerman H, Ingraham NR. Modern clinical syphilology. Philadelphia: WB Saunders, 1945;157, 351.

8 Editorial. British Fournal of Venereal Disease 1956;32:1.

9 Lowff A. Factors influencing the evolution of viral diseases of the cellular level and in the organism. Bacteriol Rev 1959;23:104-24.

10 Thompson RL, Coates MS. The effect of temperature upon the growth and survival of myxoma, herpes and vaccinia viruses in tissue cultures. $\mathcal{F}$ Infect Dis 1942;71: 83-5.

11 Nowak $T$, Niedrig $M$, Bernhardt $D$, Hilfenhaus $J$. Inactivation of $\mathrm{HIV}, \mathrm{HBV}, \mathrm{HCV}$ related viruses and other viruses in human plasma derivatives, by pasteurisation (Review). Dev Biol Stand 1993;81:169-76.

12 Orloff SL, Wallingford JC, McDougal JS. Inactivation of human immunodeficiency virus type 1 in human milk: effects of intrinsic factors in human milk and of pasteurisation. F Hum Lact 1993;9:13-7.

13 Tjotta E. Survival of HIV-1 activity after disinfection, temperature and $\mathrm{pH}$ changes or drying. $\mathcal{F}$ Med Virol 1991;35:223-7.

14 Van Bueren J. Survival of HIV and inactivation by heat and chemical disinfectants. Amsterdam: Eighth International Conference on AIDS, 1992.

15 Alonso K, Pontiggia P, Sabato A, Calvi G, Curto FC, de Bartolomei E, et al. Systemic hyperthermia in the treatment of HIV related, disseminated Kaposi's sarcoma. ment of HIV related, disseminated Kaposi's sarcoma.
Long term follow up of patients treated with low-flow extracorporeal perfusion hyperthermia. Am $\mathcal{F}$ Clin Oncol 1994;17:353-9.

16 Steinhart CR, Ash SR, Gingrich C, Sapir D, Keeling GN, Yalvin MB. Effect of whole body hyperthermia on AIDS patients with Kaposi's sarcoma: a pilot study. fournal of AIDS and Human Retrovirology 1996;11:271-81.

17 Morita M, Suzuki T, Nakajima K, Shiozawa C, Gill MJ, Hoshino $\mathrm{H}$. Characteristics and clinical significance of a stabilisation assay to detect specific antibodies to reverse stabilisation assay to detect specific antibodies to reverse
transcriptase of HIV. Clin Diagn Lab Immunol 1995;2: transcripta

18 Pennypacker C, Perelson AS, Nys N, Nelson G, Sessler DI. Localised or systemic in vivo heat inactivation of human immunodeficiency virus (HIV): a mathematical analysis. Fournal of AIDS and Human Retrovirology 1995; 8:321-9.

19 Pakianathan MR. Antiretroviral therapy; a review. Proc Roy Coll Phys Edinb 1996;26:261-4.

20 Levy JA. HIV research; a need to focus on the right target. Lancet 1995;345:1619-21. 